\title{
A KULTURÁliS PROGRAMKÍNÁLAT MEGÍTÉLÉSE A KULTÚRAFOGYASZTÁS TÜKRÉBEN- VIZSGÁLATOK DEBRECEN, GYŐR ÉS VESZPRÉM EGYETEMISTÁI KÖRÉBEN
}

\author{
Kántor Szilvia \\ Pannon Egyetem, kantor.szilvia@gtk.uni.pannon.hu
}

DOI:10.15170/TVT.2021.06.03.05

\begin{abstract}
Absztrakt
A kulturális örökség és a kulturális turizmus fogyasztásában a turisták mellett a helyi lakosok, valamint az egyetemi városok esetén az egyetemista közösség is fontos szereplőként azonosítható.

A kutatás feltárja, hogy miként vélekedik az egyetemista korosztály a városokban elérhető kulturális programkínálatról, illetve, hogy mennyire játszik fontos szerepet az ilyen jellegü szolgáltatások megléte a jövőbeli lakóhelyük megválasztásában. A vizsgálat a Debreceni Egyetemre, a Széchenyi István Egyetemre és a Pannon Egyetemre járó hallgatók körében történt online kérdőíves megkérdezéssel, melyre összesen 2066 értékelhető válasz érkezett. A kitöltők beszámoltak az egyetemi városukkal kapcsolatos véleményükröl és a szabadidejükben végzett kulturális tevékenységekröl.

Eredmények alapján a hallgatók többnyire pozitívan látják városukat és nagyra értékelik a kulturális programkínálat sokszínüségét. Emellett elmondható, hogy kapcsolat mutatható ki a szabadidős kulturális tevékenységek végzésének gyakorisága és a települési kulturális programkínálattal való elégedettség között.
\end{abstract}

Kulcsszavak: kultúrafogyasztás, egyetemisták, lakóhelyválasztás

\begin{abstract}
Besides the tourists, the local community and the university students can also be identified as important actors regarding the consumption of cultural heritage and tourism.

The research reveals what university students think about the range of cultural programs available in their cities, and how important is the existence of such services in their future residence choices. The study was conducted using an online questionnaire among the students attending the University of Debrecen, Széchenyi István University and the University of Pannonia. The total evaluable responses were 2066. The respondents reported their opinions toward their university towns and their cultural activities in their free time.

Based on the results, students mostly have a positive view on their city and the diversity of cultural program offerings. Besides, it can be said that there is a relationship between the frequency of doing leisure cultural activities and the satisfaction with the offer of the available cultural programs.
\end{abstract}

Keywords: culture consumption, university students, choice of residence 


\section{Bevezetés}

A kulturális örökség és a kulturális turizmus keresleti oldalát tekintve a turisták mellett a helyi lakosság is kiemelt szereppel rendelkezik. Az egyetemi városok esetén pedig nem szabad figyelmen kívül hagyni az egyetemista közösség jelenlétét sem, hiszen ők tevékenységükkel számos városi szolgáltatás aktív fogyasztói között találhatóak meg.

A lakosság kulturális turisztikai érdeklődése a szakirodalmi kutatások alapján pozitívan hat a desztinációk életére, hiszen a helyiektől származó bevételek hozzájárulnak a vállalkozások sikerességéhez. Emellett, nem szabad figyelmen kívül hagyni azt sem, hogy a települések kulturális kínálata sok esetben a helyi közösség kulturális attitüdjét tükrözi. Másrészt, a kulturális örökségböl való fogyasztás a lakosság életminőségét is növelheti.

Jelen kutatás középpontjában a Debreceni Egyetem, a Széchenyi István Egyetem és a Pannon Egyetem hallgatói állnak. A vizsgálat célja annak a feltárása, hogy miként vélekedik az egyetemista közösség a saját egyetemi városának kulturális életéröl, illetve, hogy milyen hatást gyakorol az ezzel való elégedettség a kulturális szabadidős tevékenységek végzésére a felsőoktatásban tanuló diákság esetén. Az adatfelvétel online kérdöív segítségével történt 2019 novembere és 2020 novembere között. Összesen 2066 válasz érkezett.

Az eredmények alapján mindhárom város hallgatói elégedettek voltak a településük kulturális életével, de bizonyos területeken jövöbeli fejlesztések szükségességét is felismerték.

\section{Szakirodalmi összefoglalás}

A kutatás középpontjában három olyan település (Debrecen, Győr, Veszprém) áll, mely nagy hangsúlyt helyez a kulturális élet és attrakciók fejlesztésére. Ezek a városok a kulturális programés szolgáltatáskínálatukat olyan eszközként azonosítják, mely kiváló lehetőséget biztosít a helyi lakosság életminőségének és kultúrafogyasztásának növelésére, a lakóhelyet keresők településre vonzására és megtartására, valamint a helykötődés és helyi identitás kialakítására.

A kulturális programok és szolgáltatások fejlesztése a rendezvények és attrakciók sokszínüségének köszönhetően nehezen választható szét a kulturális turizmus fejlesztésétől. Így a szakirodalomelemzés keretein belül a témával kapcsolatban mindenképpen érdemes szót ejteni a kulturális (turisztikai) attrakciók fogyasztóiról és a hazai kultúrafogyasztás jellemzőiről, a helyi identitás és helykötődés kialakulásáról, valamint a fiatalok lakóhelyválasztási és az egyetemisták felsőoktatási intézményválasztási preferenciáiról.

\subsection{A kulturális attrakciók és a kultúra fogyasztása hazánkban- fókuszban a helyi közösségek}

A kulturális turizmus a turizmus egy dinamikusan fejlődő ága (GÁSZNÉ BÖSZ 2020), de a kulturális jellegü attrakciók pontos lehatárolása és csoportosítása a kultúra sokszínüségének köszönhetően nehéz feladat. A különböző nevezetességek fókuszpontjai eltérőek, egyes látványosságok esetén a természeti elemek, míg másoknál a történelmi, nemzeti sajátosságok kerülnek jobban elötérbe (BONN et al. 2007). Azonban általánosságban igaznak mondható, hogy a kulturális attrakciók népszerüek a turisták (MOLINILLO - JAPUTRA 2017) és a helyi lakosok (FORMÁDI - HUNYADI 2019) körében. Fontos leszögezni, hogy bár a kultúra jelenléte sok esetben befolyásolja a látogatási kedvet, a turisták elsődleges motivációi között a tisztán kulturális indíttatás csak ritkán figyelhető meg (UNWTO 2018).

A turizmusban érintett rétegek körét nem kizárólag turisták alkotják. Napjainkban egyre hangsúlyosabb szerephez jutnak e téren a városok és a különböző desztinációk helyi lakosai (GOELDNER - RITCHIE 2012, MICHALKÓ 2010, PINKE-SZIVA 2019, SZABÓ - HOJCSKA 2020). Annak ellenére, hogy a szakirodalomban kisszámú kutatás foglalkozik a helyiek kérdésével, 
az elmúlt években végzett vizsgálatok több esetben kimutatták, hogy a népszerü turisztikai térségekben állandó lakhellyel rendelkezök turisztikai költései növelik az attrakciók sikeres müködését (MIECZKOWSKI 1981, KOVÁCS 2018, STRACK 2019, UNWTO - IPSOS, 2019). Ezen felül a társadalmi felelősségvállalásnak köszönhetően a helyiek is profitálnak a szolgáltatók jelenlétéből (STRACK 2018). Emellett, a desztinációk kulturális sajátosságai sok esetben a helyiek ízlésére épülnek (RÁTZ - PUCZKÓ 2002), valamint a helyi rendezvények (pl. fesztiválok) a lakosság életminőségét növelhetik (FORMÁDI - HUNYADI 2019). Továbbá, KOVÁCS (2018) kutatási eredményei rávilágítottak, hogy a turizmushoz köthető infrastrukturális elemeket (pl. konferenciaközpontok, szállodák) a helyi/ térségi közösség gyakran veszi igénybe családi ünnepségek megrendezése esetén.

Az állandó lakhellyel rendelkezők fogyasztásai mellett érdemes górcső alá venni a településeken tartózkodási hellyel rendelkező egyéneket, hiszen ök is használják a turisztikai infrastruktúra különböző elemeit (pl. vendéglátás, rekreációs szolgáltatások stb.). Közülük kiemelt helyet foglalnak el az egyetemisták, akik lakóhelyválasztási és utazási döntéseivel, valamint jelenlétük gazdasági hatásaival számos kutatás foglalkozott a közelmúltban (ÁRVA - KÖNYVES 2010, SOKOŁOWICZ 2019, XIE - RITCHIE 2019).

Érdemes kiemelni, hogy a kulturális turizmus a szabadidő minőségi eltöltése mellett más módokon is hatást gyakorolhat a helyi közösségek életére, jólétére. Egyrészt munkahelyet biztosít (ISTÓK 2004), másrészt pedig a helyi hagyományok és értékek ápolásában és megóvásában játszik szerepet (TÓTHNÉ KARDOS 2016). Mindezeken túl a helyiek igényeit figyelembe vevő fejlesztési törekvések a települések és desztinációk versenyképességét is meghatározhatják, melyek eredményeként nem csupán a közösségi terek újulhatnak meg, de a kulturális jellegü szolgáltatások számában növekedés következhet be. Ez elősegítheti az életkörülmények javulását, a települések vonzó lakóhelyként való megjelenését, valamint az objektív és szubjektív életminőség növekedését (RUDAN 2010, VONG 2013, RÁTZ 2014).

A kultúrafogyasztást egyébként számos tényező befolyásolja. A jövedelmi helyzet és a kulturális szolgáltatások árai mellett (KSH 2018), az életkor (PAVLUSKA - JAKOPÁNECZ - TÖRÖCSIK 2018. 2018), az iskolázottság (CSAPÓ et al. 2018), a vallás (PUSZTAI 2011) és a lakóhely (SZÉKELY - SZABÓ 2017) is képes rá hatást gyakorolni.

A témával kapcsolatos kutatások alapján elmondható, a 18-30 év közöttiek körében a populáris kultúra elemei örvendtek a legnagyobb népszerüségnek. Ilyenek például a könnyüzenei fesztiválok, a szórakozóhelyek rendezvényein való részvétel, vagy a zenehallgatás. A könnyen emészthető, populáris kultúra népszerüségét mutatja, hogy a felmérésekbe bevont fiatalok a müvészeti ágak közül a pop, a rock, a modern tánc és az utcai müvészet (street art) iránt mutatták a legnagyobb érdeklődést. A hagyományosan magas kulturális értekkel bíró müfajokat, mint például az operát, a balettet, a klasszikus zenét és a festészetet szinte teljes mértékben elutasítottak a válaszadók. A kutatási jelentések rámutattak, hogy a színház, a musical és az irodalom iránt sem lelkesedtek igazán a fiatalok (FANTA TRENDRIPORT 2008).

Ezzel összhangban FORMÁDI és szerzőtársai (2019) kutatásaik során kimutatták, hogy az Y generáció számára a könnyedebb kulturális értékek felfedezése, valamint a gasztronómiai jellegü élmények gyüjtése nagyobb hangsúlyt kap a szabadidős utazások alkalmával, mint az idősebb generációk esetén.

\subsection{Helyi identitás és helykötődés}

HIDALGO és HERNÁNDEZ (2001) szerint a helykötődés nem más, mint a helyek és az emberek közötti érzelmi kapcsolat, ami gyakran egy bizonyos hely iránti elköteleződés formájában jelenik meg a modern társadalmakban (MARIEN 2013). URBÁNNÉ TREUTZ (2017) munkája alapján a 
helykötődés három lépcső mentén írható le a legjobban. Legtágabb értelmezésben „generikus helyfüggöségröl” beszélhetünk, mely esetén nem a helyhez, hanem inkább annak bizonyos tulajdonságaihoz köthető a kötődés. Ennél szükebb értelmezés esetén földrajzi helydependencia figyelhető meg, ahol már erősebb a kapcsolat a hely és az ember között. A legszükebb felfogás a helykötődés vagy a helyi identitás, melyben erős egyéni jelentéstartalom mutatható ki, valamint az egyén és az adott helyszín között kapcsolat hosszabb múltra tekint vissza (DÚLL 2009, URBÁNNÉ TREUTZ 2017).Ettől eltérően LIVINGSTON, BAILEY és KEARNS (2008) szerint a fogalom könnyebb értelmezése érdekében érdemesebb az emocionális és a funkcionális helykötődést elkülöníteni. Az előbbi inkább az élményszerzésre, az utóbbi pedig az életstílusra utal.

SCANNELL és GIFFORD (2010) komplex módon közelített a helykötődés felé. Munkájukban három fő dimenzió különítenek el. Az első a személy, aki személyes tapasztalatai, vallási és történelmi érzései, valamint a különböző kulturális csoportokhoz való tartozás alapján alakítja ki a helyhez való kötődése nagyságát. A második dimenzió a hely, ami egyszerre szociális és fizikai tér, a maga természeti és építészeti környezetének minden sajátosságával. A harmadik dimenzió pedig a folyamat, ami összekapcsolja a személyt és a helyet. Ezt az érzelmek (boldogság, büszkeség, szeretet), a megismerés (emlékezet, ismeret, sémák, jelentés) és a viselkedés (közelség fenntartása, hely újjáépítése) ötvözésével képes elérni.

Az identitás-alapú megközelítések egyre hangsúlyosabban kerülnek előtérbe a városmarketinggel kapcsolatban (PISKÓTI 2016). EBERLE GAMBERG és GRAMBERG (2004) tanulmányukban öt elemet különböztetnek meg egymástól a városidentitással összefüggésben. Ezek a városkép, az életminőség, az értékek, a munkalehetőség és a bérek, valamint az anyagi erőforrások és terhek. EBERT (2004) szerint két elemre érdemesebb fókuszálni a témával kapcsolatban. Ezek a településről kialakult kép és összebenyomások, valamint maga az egyén és az ő hellyel kapcsolatban kialakított kötődései. Azt azonban le kell szögezni, hogy a városról kialakult képet jelentősen meghatározzák a benne élő egyének és az ő településsel kapcsolatos meglátásaik (PISKÓTI 2016). KERR és OLIVER (2015) munkája is ezt erősíti, a szerzőpáros tanulmányában szintén a helyi lakosok és a helyröl mutatott kép közötti eröteljes kapcsolatot hangsúlyozzák, rámutatnak, hogy az effajta belső tényezők mellett a külső hatások is befolyásolják a városokról elénk táruló képet és ezáltal a helykötődést.

A turizmus szintén képest hatást gyakorolni a helykötődés kialakulására. SZABÓ (2020) szerint a turistákban utazásaik során gyakran alakul ki egyfajta kötődés a meglátogatott desztinációk iránt, mely pozitívan befolyásolhatja az adott település vagy régió életét. Egyrészt, a helyi tradíciók megismerése által nagyobb felelösségtudat alakulhat ki a vendégekben a hagyományokat örző lakosokkal szemben. Másrészt pedig a helyiekkel kapcsolatos szimpátia fenntartható viselkedésre ösztönözheti a vendégeket.

\subsection{Fiatalok lakóhelyválasztási preferenciái}

A magyar lakosság lakóhelyválasztási döntéseit több hazai kutatás vette górcső alá az elmúlt években. Ezek eredményei alapján elmondható, hogy a letelepedés szempontjából azok a települések tudnak versenyképesek maradni, ahol biztosítottak a társadalmi, gazdasági és környezeti infrastruktúra elemei, valamint a helyiek magas életszínvonala. A magyarok azokra a helyekre költöznek szívesen, ahol megfelelő a közbiztonság, az infrastruktúra, a lakókörnyezet állapota, valamint az egészségügyi szolgáltatások színvonala. Ezzel szemben a zsúfolt, szennyezett és egészségtelen lakókörnyezetet és az ellenséges lakóközösségeket kifejezetten kerülik a letelepedni vágyók (KOLTAI - GALAMBOSNÉ TISZBERGER 2014, KOLTAI 2014, FEKETEBERZSENYI 2018).

A kutatás középpontjában álló egyetemista korosztály lakóhelyválasztási döntéseivel több tanulmány foglalkozott a közelmúltban. FRENKEL, BENDIT és KAPLAN 2013-as kutatásai 
szerint az egyetemet frissen befejezett hallgatók több szempontot vesznek figyelembe lakóhelyük megválasztása során. A települések gazdasági és társadalmi helyzete kiemelkedő jelentőséggel bír, de a lakhatási körülmények és annak költségei is meghatározóak. Döntéseik meghozatalánál a fentieken kívül figyelembe veszik még a munkahelyükre történő bejárással kapcsolatos költségeket és időt, valamint a településeken elérhető kulturális program- és szolgáltatáskínálat mennyiségét és minőségét. A kulturális és szabadidős rendezvények és események szerepének fontosságát SOKOŁOWICZ (2019) kutatásai szintén megerősítették.

Általánosságban elmondható, hogy azok a települések, melyek sokszínü kulturális élettel rendelkeznek, kedvelt célpontot jelentenek a magasabb végzettséggel rendelkező, kreatív és innovatív emberek számára. A kulturális életbe sokat fektető települések tehát képesek magukhoz vonzani és megtartani a jól kvalifikált munkavállalókat (LANDRY - WOOD, 2003 in PÁLFI, 2019).

2019-ben KOVÁCS és GÖRÖG a Szegedi Tudományegyetemen végeztek vizsgálatokat azzal kapcsolatban, hogy az alapszakos hallgatók milyen szempontokat vesznek figyelembe, amikor mesterképzésük „otthonául” szolgáló települést választanak. A végzés közelében és a frissen végzett hallgatók körében a legfontosabb tényezők a bérek, az életszínvonal, a lakókörnyezet, valamint a szabadidős szórakozási és pihenési lehetőségek voltak.

A hallgatóknak kívánatosak a vonzó és élhető települések (KURÁTH - SIPOS 2019), melyek kiemelkedő szórakozási és kikapcsolódási lehetőségeket kínálnak számukra (CSUKA - BANÁSZ 2014). Fontos leszögezni, hogy a diákok felsőoktatási intézmény választási döntéseik során először szakot, majd egyetemet választanak, csak ezután kerül sorra a városról való döntés. Így az intézmények presztízse és a kínált szakok mennyisége és minőségi szintén fontos szempont a hallgatók számára (KOSZTYÁN et al. 2019).

\section{Módszertan}

Jelen kutatás célja annak a feltárása, hogy hogyan befolyásolja az egyetemista közösséget a kulturális programkínálat a szabadidős tevékenységek megválasztásában és az egyetemi városukkal való megelégedettségében. A vizsgálat középpontjában a Debreceni Egyetem, a Széchenyi István Egyetem és a Pannon Egyetem hallgatói álltak.

A kutatás kezdetén felállított kutatási kérdések a következők voltak:

- K1: Milyennek látják egyetemi városukat (Debrecen, Győr, Veszprém) a hallgatók?

- K2: Mennyire fontosak a kulturális szabadidős tevékenységek a lakóhely megválasztási döntéseikben?

- K3: Melyek azok a területek, amelyeknél fejlesztések eszközölését látják szükségesnek a hallgatók?

- K4: Milyen típusú szabadidős tevékenységet végeznek a hallgatók a leggyakrabban?

- K5: Milyen kapcsolat figyelhető meg a városokban elérhető kulturális programkínálattal elégedett hallgatók és a különböző kulturális szabadidős tevékenységek végzése között?

Az irodalmi áttekintés és a kutatási kérdések alapján az alábbi hipotézisek kerültek megfogalmazásra:

- H1: A kutatásba bevont egyetemisták számára fontos, hogy lakóhelyük a jó társadalmi (pl. település közösségi élete) és gazdasági (pl. munkalehetőségek, infrastruktúra, lakhatási és 
megélhetési költségek) adottságok mellett kulturális szolgáltatásokat és programokat is kínáljon számukra.

- H2: A felmérésben részt vevő hallgatók leginkább a populáris kultúra iránt érdeklődnek.

- H3: A kulturális fogyasztásban aktívabb hallgatók elégedettebbek a városuk kulturális életével.

A kutatás kvantitatív jellegü, az adatfelvétel online kérdőíves megkérdezés segítségével történt a három egyetemi város (Debrecen, Győr, Veszprém) hallgatóinak körében 2019 novembere és 2020 novembere között. A kérdőív tesztelése a Pannon Egyetemre járó felsőoktatási szak-, alap-, mester, illetve PhD képzésre járó hallgatók bevonásával történt 2019 novemberében. A véglegesített elektronikus kérdőív a közösségi média olyan csoportjaiban került megosztásra, melynek tagjai a kutatás célcsoportját képező egyetemisták voltak. Az adatfelvétel véletlen mintavétel keretein belül történt. A kérdőív használata lehetővé tette az adatok sztenderdizált formában való begyüjtését (MITEV 2019).

A kérdőív hat főbb blokkból állt, melyből jelen kutatáshoz három kérdéscsoport került felhasználásra (demográfia, szabadidős tevékenységek, települési sajátosságok értékelése). Összesen 2066 darab értékelhető válasz érkezett, melyből 1139-et a Debreceni Egyetem, 626-ot a Széchenyi István Egyetem és 301-et a Pannon Egyetem hallgatói küldtek be. A beérkezett kitöltésekkel kapcsolatban elmondható, hogy a hallgatói szám tekintetében reprezentatív a kutatás, hiszen mindhárom intézmény esetén az összhallgatói létszám 5\%-a válaszolta meg a kérdéséket.

A válaszok begyüjtése a Limesurvey kérdöívszerkesztő szoftver, az eredmények kiértékelése és a statisztikai elemzések pedig az SPSS Version 25 és az Excel programcsomagok segítségével történtek.

\section{A kutatás eredményei}

Elsőként a kitöltők demográfia és képzési adatai kerülnek bemutatásra. A kitöltő hallgatók 71,4\%a nő, 28,6\%-a férfi volt. Az életkoruk 18 és 57 év között mozgott, melynek oka, hogy levelezös hallgatók is képviseltették magukat a mintában. Az átlagéletkor 23,02 év, az életkorok mediánja 21, módusza pedig 20 év volt.

Az állandó lakóhely szerinti megoszlás az 1. ábrán látható.

\section{8. ábra. A kitöltők állandó lakóhely szerinti megoszlása}

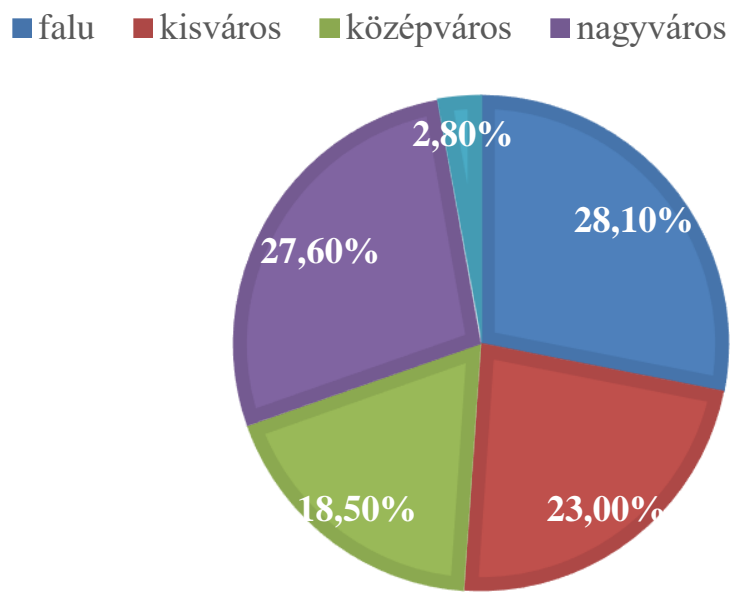

Forrás: saját szerkesztés a kérdöives felmérés alapján 
A válaszadók többsége faluban (5000 fönél kisebb település) és nagyvárosban (100 ezer és 1 millió fö közötti település) élt, de jelentős még a kisvárosokban (5 és 20 ezer fó), valamint a középvárosokban (20 és 100 ezer) lakók aránya. Legkisebb százalékban a metropoliszok (1 millió fönél nagyobb) lakosai voltak megtalálhatóak a mintában.

A kitöltő hallgatók többsége a tanulmányai alatt kollégiumban (31,5\%), vagy szülőkkel közösen a családi otthonban (30,7\%) lakott, rajtuk kívül albérletben $(21,8 \%)$ és saját ingatlanjukban $(14,5 \%)$ éltek még a hallgatók. 1,5\%-uk jelölte ennél a kérdésnél az egyéb opciót.

A képzési adatokkal kapcsolatban elmondható, hogy a kitöltők legnagyobb része a Debreceni Egyetemröl (55,1\%) érkezett, ezt követte a Széchenyi István Egyetem (30,3\%) és a Pannon Egyetem $(14,6 \%)$.

A képzési szint szerinti megoszlás a 2. ábrán látható.

\section{9. ábra. A hallgatók képzési szint szerinti megoszlása}

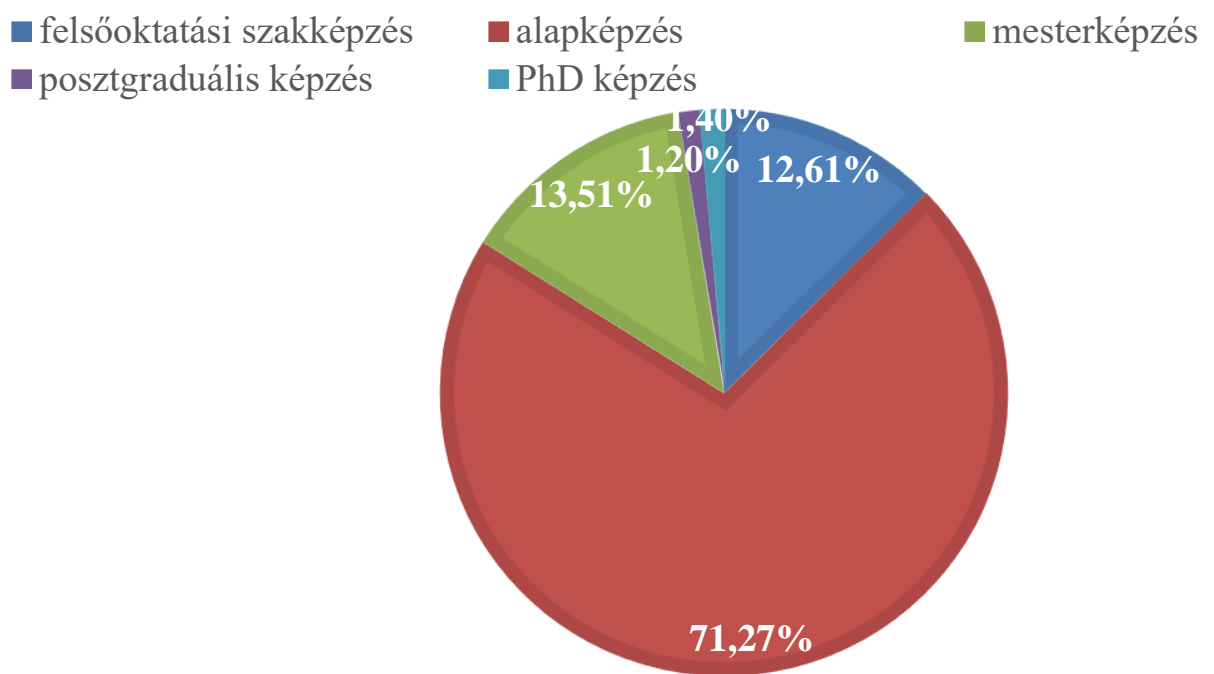

Forrás: saját szerkesztés a kérdöives felmérés alapján

Ahogy a 2. ábra mutatja a válaszadók jelentős többsége alapképzésre járt, ezt követte a mesterképzés, a felsőoktatási szakképzés, a $\mathrm{PhD}$ képzés, valamint a posztgraduális képzés. A képzési forma tekintetében elmondható, hogy a kitöltők 81,9\%-a nappali, 18,9\%-a pedig levelezö tagozatos volt.

A demográfia és a képzési adatok után a hallgatók arról is beszámoltak, hogy milyennek látják a várost, ahol tanulmányaikat folytatják. Ennek vizsgálatára azt kértem a hallgatóktól, hogy egy 10 elemből álló listát értékeljenek aszerint, hogy mennyire tartják azt igaznak az egyetemi városuk esetén. Az értékelést egy 1-5-ig tartó skálán tehették meg, ahol az 1= teljes mértékben egyetértek, és $5=$ egyáltalán nem értek egyet.

A lista az alábbi jellemzőkből állt: modern, csendes, tiszta, „zöld”, biztonságos, vendégszerető, kulturálisan pezsgő, turisztikai célpont, ipari központ, folyamatosan fejlődő.

A hallgatók által a különböző jellemzőkre adott értékelések városonként (átlag, módusz) az 1. táblázatban kerültek összefoglalásra. Mivel a skála fordított $(1=$ teljes mértékben egyetértek, $5=$ egyáltalán nem érték egyet), így minél alacsonyabbak a táblázatban szereplő értékek, annál igazabbnak gondolják azt a hallgatók saját egyetemi városukra nézve. 
2. táblázat. A városi jellemzőkre adott értékelések

\begin{tabular}{|l|l|l|l|l|l|l|l|}
\cline { 2 - 8 } \multicolumn{1}{c|}{} & \multicolumn{2}{l}{ Debrecen } & \multicolumn{2}{l|}{ Győr } & \multicolumn{2}{l|}{ Veszprém } \\
\cline { 2 - 8 } \multicolumn{1}{c|}{} & átlag & módusz & átlag & módusz & átlag & módusz \\
\hline modern & 2,79 & 2 & 2,40 & 2 & 3,09 & 3 \\
\hline csendes & 3,077 & 4 & 3,05 & 3 & 2,48 & 2 \\
\hline tiszta & 2,526 & 2 & 2,25 & 2 & 2,2 & 2 \\
\hline „zöld” & 2,58 & 2 & 2,50 & 2 & 2,42 & 2 \\
\hline biztonságos & 2,252 & 2 & 2,27 & 2 & 2,05 & 2 \\
\hline vendégszerető & 2,241 & 2 & 2,02 & 2 & 1,96 & 2 \\
\hline kulturálisan pezsgő & 2,221 & 2 & 1,91 & 1 & 2,26 & 2 \\
\hline turisztikai célpont & 2,391 & 2 & 2,09 & 2 & 2,22 & 2 \\
\hline ipari központ & 3,145 & 3 & 2,13 & 1 & 3,36 & 4 \\
\hline folyamatosan fejlődő & 2,054 & 2 & 1,62 & 1 & 2,15 & 2 \\
\hline
\end{tabular}

Forrás: saját szerkesztés a kérdöives felmérés alapján

Ahogy a táblázatból kiolvasható csekély különbségek figyelhetőek meg a hallgatók véleményében a városokról kialakult kép tekintetében. A kitöltők válaszai alapján Debrecen kulturálisan pezsgő, turisztikai célpont és egy folyamatosan fejlődő település. Ehhez hasonlóan Győr tiszta, biztonságos, vendégszerető, kulturálisan pezsgő, érdekes turisztikai célpont, ipari központ és egy folyamatosan fejlődő város. Veszprémet már kicsit másképp látták a hallgatók, szerintük a város folyamatosan fejlődő, tiszta, biztonságos, vendégszerető, kulturálisan pezsgő és kedvelt turisztikai célpont.

A hallgatók arról is számot adtak, hogy véleményük szerint milyen típusú fejlesztéseket lenne érdemes eszközölni az egyetemi városukban. Ezzel kapcsolatban egy nyolc elemü listából kellett kiválasztaniuk azt a három fejlesztési irányt, melyet szükségesnek tartanak a települések jobbá tétele érdekében. Ez a 3. ábrán került összefoglalásra. 


\section{0. ábra. Hallgatók által meghatározott fejlesztési irányok}

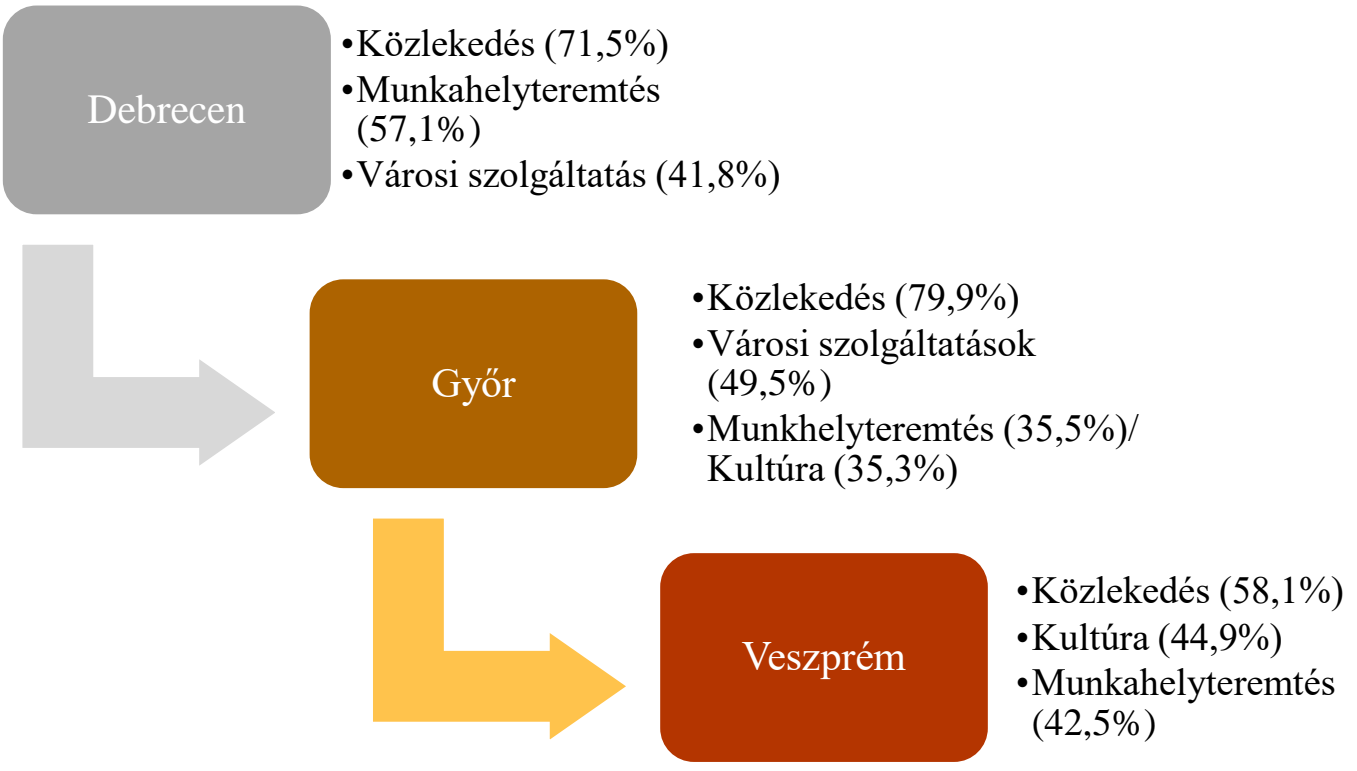

Forrás: saját szerkesztés a kérdöíves felmérés alapján

Ahogy a 3. ábra mutatja, a hallgatók véleményében kevés eltérés figyelhető meg, a fejlesztési irányok egybecsengenek.

Ezt követően a kitöltők egy 1-5 tartó skálán (ahol az 1= egyáltalán nem fontos, és 5= nagyon fontos) értékelték az általam felsorolt tényezőket és azok fontosságát lakóhelyválasztási döntéseik meghozatalakor (2. táblázat). 
3. táblázat. A lakóhelyválasztást befolyásoló tényezők fontosságának átlaga

\begin{tabular}{|l|l|}
\hline Tényező & Átlag \\
\hline munkalehetőségek & 4,67 \\
\hline lakhatási és megélhetési költségek & 4,66 \\
\hline közbiztonság & 4,43 \\
\hline egészségügyi szolgáltatások & 4,43 \\
\hline település megközelíthetősége & 4,40 \\
\hline infrastruktúra & 4,33 \\
\hline pihenési, feltöltődési lehetőségek & 3,86 \\
\hline vásárlási lehetőségek & 3,86 \\
\hline helyi tömegközlekedés & 3,72 \\
\hline kulturális szolgáltatások & 3,62 \\
\hline parkolási lehetőségek & 3,60 \\
\hline szórakozási lehetőségek & 3,56 \\
\hline városi szolgáltatások & 3,43 \\
\hline kulturális rendezvények & 3,34 \\
\hline település közösségi élete & 3,17 \\
\hline kerékpározási lehetőségek & 2,94 \\
\hline városi szabadidős programok & 2,89 \\
\hline művészeti közösségek & 2,63 \\
\hline
\end{tabular}

Forrás: saját szerkesztés a kérdöíves felmérés alapján

A táblázatban szereplő eredmények alapján elmondható, hogy a hallgatók számára a legfontosabbak a munkalehetöségek $(4,67)$, a lakhatási és megélhetési költségek $(4,66)$, a közbiztonság $(4,43)$, az egészségügyi szolgáltatások $(4,43)$ és a település megközelíthetősége $(4,4)$ voltak, de a közepesnél (3) magasabbra értékelték a kulturális szolgáltatások $(3,62)$ és rendezvények $(3,34)$ meglétét is.

A hallgatók az általuk végzett szabadidős tevékenységekről is számot adtak. Ehhez a kitöltőknek egy 16 elemü, kulturális jellegü szabadidős tevékenységeket tartalmazó lista esetén kellett kiválasztaniuk, hogy milyen gyakran (soha; ritkábban, mint évente; évente néhányszor; havonta néhányszor; hetente néhányszor; naponta) végzik az adott tevékenységeket.

Az eredmények szerint a hallgatók leggyakrabban az alábbiakkal töltik szabadidejüket:

- újságolvasás;

- rádióhallgatás, tévénézés;

- könyvolvasás. 
A legritkábban pedig az alábbiakkal foglalkoztak:

- hangversenyen való részvétel;

- művészeti kiállítások és múzeumok látogatása;

- müvészmozi vetítésen való részvétel.

Intézményenként szinte egyáltalán nem volt különbség a kitöltők szokásai között, de elmondható, hogy Debrecen válaszadói többször ülnek le a tv és rádió elé, a Veszprém diákságát képviselö kitöltők pedig a müvészeti tevékenységek végzése terén aktívabb.

A kulturális élettel való elégedettség és a végzett kulturális szabadidős tevékenységek közötti kapcsolatot a Kendall-féle tau $(\tau)$ használatával vizsgáltam. A kulturális élettel való elégedettséget a „Mennyire tartja kulturálisan pezsgőnek az egyetemi települését?” kérdéssel mértem, mely esetében egy 1-5-ig tartó skálán tehették meg, ahol az 1= teljes mértékben egyetértek, és 5= egyáltalán nem értek egyet.

A Kendall-féle tau $(\tau)$ alkalmazásának oka, hogy mindkét változó numerikus és sorrendi, valamint, hogy az adatok nagy számban tartalmaznak azonos rangszámokat (MALHOTRA - SIMON 2017). A mérőszám a Pearson-féle korrelációs együtthatóhoz hasonlóan értelmezhető. Ha a tau $(\tau)$ értéke 0 alatti nincs, ha 0,2 alatti gyenge, ha 0,2-0,7 közötti közepesen erős, ha 0,7 feletti akkor pedig erős kapcsolat feltételezhetö (SAJTOS - MITEV 2007). A rangkorrelációs vizsgálat eredményeként kapott $\tau$ értékek a 3. táblázatban kerültek bemutatásra.

4. táblázat: A rangkorrelációs vizsgálat eredménye (Kendall-féle tau ( $\tau)$ értékek)

\begin{tabular}{|l|l|}
\hline $\begin{array}{l}\text { Szabadidös tevékenységek végzésel kulturális élettel való } \\
\text { elégedettség }\end{array}$ & $\begin{array}{l}\text { Mennyire tartja } \\
\text { kulturálisan pezsgőnek a } \\
\text { települést? }\end{array}$ \\
\hline könyvtárba járás & - \\
\hline színházi elóadás megtekintése & $-0,039$ \\
\hline multiplex mozi látogatás (pl. Cinema City) & - \\
\hline müvészmozi látogatás & - \\
\hline hangversenyen való részvétel & - \\
\hline könnyüzenei koncert meghallgatása & $-0,039$ \\
\hline $\begin{array}{l}\text { kulturális rendezvény (pl. gasztronómiai vagy múvészeti } \\
\text { fesztivál) meglátogatása }\end{array}$ & $-0,039$ \\
\hline múvészeti kiállítás vagy múzeum meglátogatása & - \\
\hline rádióhallgatás, tévénézés & $-0,044$ \\
\hline könyvolvasás & - \\
\hline újságolvasás (online vagy offline) & - \\
\hline $\begin{array}{l}\text { múvészeti tevékenység végzése (pl. tánc, zenélés, festészet, } \\
\text { fotózás) }\end{array}$ & - \\
\hline szórakozóhely, kocsma látogatása & - \\
\hline étterem, kávézó szolgáltatásainak igénybe vétele & - \\
\hline vásárolgatás & - \\
\hline sportrendezvényeken való részvétel (nézöként) & $-0,069$ \\
\hline
\end{tabular}

Forrás: saját szerkesztés a kérdöives felmérés alapján

Ahogy a táblázatból kiolvasható 5 esetben figyelhető meg szignifikáns kapcsolat a tényezök között (a kihúzott négyzetek a nem szignifikáns kapcsolatokat jelölik). A szignifikáns eredmények 
mindegyike gyenge kapcsolatot feltételez $(\tau<0,2)$. A vizsgálat alapján elmondható, hogy azok a hallgatók, akik kulturálisan pezsgőbbnek tartják egyetemi városukat gyakrabban járnak színházba, könnyüzenei koncertekre, kulturális rendezvényekre, valamint sportrendezvényekre, illetve többször ülnek le a rádió és televízió elé.

\section{4. Összegzés}

Jelen kutatás célja annak a bemutatása volt, hogy miként vélekedik az egyetemista közösség Debrecen, Győr és Veszprém kulturális programkínálatáról és a városi kulturális szolgáltatások színvonaláról. Emellett górcső alá került, hogy melyek azok a kulturális tevékenységek, amiket a hallgatók gyakran végeznek szabadidejükben, illetve, hogy mennyire befolyásolja ezt a kulturális programkínálattal való elégedettségük.

A kutatás kezdetén felállított első hipotézis, mely szerint a kutatásba bevont egyetemisták számára fontos, hogy lakóhelyük a jó társadalmi (pl. település közösségi élete, közbiztonsága) és gazdasági (pl. munkalehetőségek, infrastruktúra, lakhatási és megélhetési költségek) adottságok mellett kulturális szolgáltatásokat és programokat is kínáljon számukra csak részben nyert igazolást. A kérdőíves felmérés eredményei alapján a vizsgálatban részt vevő hallgatók számára leginkább a gazdasági tényezők a fontosak (pl. munkalehetőségek, lakhatási és megélhetési költségek), ezt követik a közbiztonság, az egészségügy és a megközelíthetőség. A társadalmi szempontok (pl. közösségi élet, müvészeti közösség) azonban háttérbe szorulnak a lakóhelyválasztás során. Ezzel szemben a kulturális szolgáltatások és programok fontosságát közepesre értékelték a kitöltők. A városokban szükséges fejlesztéseket szinten a fentiekkel kapcsolatban azonosították (pl. közlekedés, munkahelyteremtés, kultúra).

A második hipotézis, melyben azt állítom, hogy a felmérésben részt vevő hallgatók leginkább a populáris kultúra iránt érdeklődnek bizonyítást nyert. A kitöltők a „kevesebb erőfeszítést” igénylő tevékenységeket (újságolvasás, rádióhallgatás, tévénézés, könyvolvasás) részesítik előnyben a magaskultúra elemeivel szemben (pl. hangversenyek, kiállítások, múzeumok, művészmozik).

A harmadik hipotézis, mely szerint a kulturális fogyasztásban aktívabb hallgatók elégedettebbek a városuk kulturális életével igazolást nyert, hiszen azok a hallgatók, akik gyakrabban végeznek kultúrára épülö szabadidős tevékenységet városuk kulturális életével is elégedettebbnek mutatkoznak.

Az eredmények alapján elmondható továbbá, hogy az egyetemisták alapvetően pozitívan tekintenek saját egyetemi városukra. Mindhárom települést a turizmusban kiemelkedő, pezsgő kulturális élettel rendelkező, folyamatosan fejlődő városként jellemezték a kitöltők.

Összeségében elmondható, hogy a megkérdezett egyetemisták számára a kulturális programkínálat megléte fontos szerepet játszik abban, hogy hova költöznek a jövőben, illetve abban, hogy milyen gyakran fogyasztják a kultúra különbözö elemeit. Ezek a tényezök tehát nagymértékben meghatározzák a település iránt érzett kötődés és identitás mértékét is.

\section{Irodalomjegyzék}

ÁRVA, L. - KÖNYVES, E. (2010): Educational Tourism and lts Effects on Regional Economy and Destination Management. In: Constructing Central Europe: Tourism Competitiveness. Pannon University Conference Papers, Veszprém, pp. 283-299.

BONN, M. A. - JOSEPH-MATHEWS, S. M. - DAI, M. - HAYES, S. - CAVE, J. (2007): Heritage/Cultural Attraction Atmospherics: Creating the Right Environment for the Heritage/Cultural Visitor. Journal of Travel Research 45(3), pp. 345-354. 
CSAPÓ, J. - GERDESICS, V. - GONDA, T. - RAFFAY, Z. - TÖRÖCSIK, M. (2018): Turizmus. A magyar lakosság turizmussal kapcsolatos beállitódása generációs szemléletü vizsgálattal. Kézirat. [Számítógép-fáj1]. EFOP-3.6.1-16-2016-00004, Pécs, PTE KTK

CSUKA, GY. - BANÁSZ, ZS. (2014): Lehetőségek és döntések - a felsőoktatási intézményválasztási szempontok változása, Educatio, 2014/4., pp. 616-631.

DÚLL, A. (2009). A környezetpszichológia alapkérdései. Helyek, tárgyak, viselkedés. L'Harmattan, Budapest

EBERLE GRAMBERG, G. - GRAMBERG, J. (2004): Stadtidentität. In HILBER, M. L., ERGEZ, A. (eds.), Stadtidentität. Der richtige Weg zum Stadtmarketing

EBERT, C. (2004): Identitätsorientiertes Stadtmarketing: Ein Beitrag zur Koordination und Steuerung des Stadtmarketing, Schriften zu Marketing und Management, No. 50, Peter Lang International Academic Publishers, Berlin

FANTA TRENDRIPORT 2008 (kutatásvezető: Ságvári Bence) Elérhető: http://www.brandtrend.hu/musor/FantaTrendriport_6.pdf (letöltve: 2019.02.16.)

FEKETE-BERZSENYI, H. (2019): Versenyképesség a Balaton Régió településein - a települési tényezők lakossági megítélése. Comitatus: Önkormányzati Szemle 232, pp. 82-94.

FORMÁDI, K. - HUNYADI, ZS. (2019): Helyi büszkeség vagy bosszúság?! A fesztiválok hatása a települések életében. PROSPERITAS V.I. Paper: No 4. pp. 95-111. DOI: 10.31570/Prosp_2019_04_6

FORMÁDI, K. - PETYKÓ, CS. - SZALÓK, CS. - JUSZTIN, M. - HOLCZERNÉ SZENTIRMAI, Á. (2019): Motivált utazók, inspiráció és élménykeresők - avagy az Y generáció utazási szokásainak elemzése. Turisztikai és Vidékfejlesztési Tanulmányok, IV. évf. IV. szám. pp. 11-22. DOI: 10.15170/TVT.2019.04.04.02

FRENKEL, A. - BENDIT, E., - KAPLAN, S. (2013): Residential location choice of knowledgeworkers: The role of amenities, workplace and lifestyle. Cities, 35, pp. 33-41.

GÁSZNÉ BŐSZ, B. (2020): Dél-Dunántúl, a kulturális turisztikai régió? Turisztikai és Vidékfejlesztési Tanulmányok, V. évf. III. szám, pp. 74-90. DOI: 10.15170/TVT.2020.05.03.05

GOELDNER, C. R. - RITCHIE, J. R. B. (2012): Tourism-Principles, Practices, Philosophies. John Wiley and Sons, Inc., New Jersey

HIDALGO, M. C., - HERNÁNDEZ, B. (2001). Place attachment: conceptual and empirical questions. Journal of Environmental Psychology 21, pp. 273-281.

ISTÓK, CS. (2004): A fenntartható turizmus megvalósítása, megőrzése és fejlesztése Hajdúszoboszlón. Turizmus Bulletin VII. évfolyam, 3. szám, pp. 25-32.

KERR, G. - OLIVER, J. (2015). Rethinking place identities. In KAVARATZIS, M., WARNABY G., \& ASHWORTH, G. J. (Eds.) (2015), Rethinking place branding. Zürich, Switzerland: Springer. pp. 66-70.

KOLTAI, Z. - GALAMBOSNÉ TISZBERGER, M. (2014): Nagyvárosok helyzeti előnybenPiackutatás a magyar települések sikerességéröl. Tér-gazdaság-ember, 2:1, pp. 25-40.

KOLTAI, Z. (2014): Dél-dunántúli települések egy országos piackutatás tükrében. Deturope 6:3, pp. 54-68. 
KOSZTYÁN, ZS. T. - BANÁZS, ZS. - CSÁNYI, V. V. - NEUMANNÉ VIRÁG, I. - TELCS, A. (2019): A hallgatói mobilitás vizsgálata gazdasághálózati módszerekkel. Statisztikai Szemle, 97:11, pp. 1007-1049.

KOVÁCS, A. (2018): Helyi vagyok - vagy turista? avagy a helyi lakosság, mint potenciális turisztikai célcsoport. In CSAPÓ, J.- GERDESICS, V.- TÖRÖCSIK, M. (eds.): Generációk a turizmusban. I. Nemzetközi Turizmusmarketing Konferencia: Tanulmánykötet, Pécsi Tudományegyetem Közgazdaságtudományi Kar, Pécs, pp. 260-267

KOVÁCS, P. - GÖRÖG, V. (2019): Egyetemek hallgatói megtartóképessége. Köz-Gazdaság, 2019/1, pp. 24-29.

KÖZPONTI STATISZTIKAI HIVATAL (KSH) (2018): Magyarország, 2017. Elérhető: http://www.ksh.hu/docs/hun/xftp/idoszaki/mo/mo2017.pdf (letöltve: 2019.01.25.)

KURÁTH, G. - SIPOS, N. (2019b): Felsőoktatási jelentkezések- új hallgatók, új módszerek? Magyar Tudomány. 180:8, pp. 1166-1174.

LIVINGSTON, M. - BAILEY, N. - KEARNS, A. (2008): People's attachment to place - The influence of neighbourhood deprivation. Glasgow University, Glasgow

MALHOTRA, N. K. - SIMON, J. (2017): Marketingkutatás. Akadémiai Kiadó, Budapest

MARIEN, A. (2013): A helykötődés és a migrációs szándék kapcsolata globalizálódó világunkban. In: KARLOVITZ, J. T. (szerk.) Ekonomické štúdie - teória a prax: Gazdasági tanulmányok elmélet és gyakorlat. 566 p.Konferencia helye, ideje: Komárno, Szlovákia, 2013.01.22-2013.01.23. Komárno: International Research Institute, pp. 431-438.

MICHALKÓ, G. (2010): Boldogitó utazása turizmus és az életminőség kapcsolatának magyarországi vonatkozásai. Második, javított kiadás. MTA Földrajztudományi Kutatóintézet, Budapest

MIECZKOWSKI, Z. T. (1981): Some Notes On The Geography Of Tourism: A Comment. The Canadian Geographer / Le Géographe Canadien 25(2), pp. 186-191.

MITEV, A. Z. (2019): Kutatásmódszertan a turizmusban. Akadémiai Kiadó, Budapest

MOLINILLO, S. - JAPUTRA, A. (2017): Factors influencing domestic tourist attendance at cultural attractions in Andalusia, Spain. Journal of Destination Marketing \& Management 6(4), pp. 456-464. DOI: 10.1016/j.jdmm.2016.09.011

PAVLUSKA, V. - JAKOPÁNECZ, E. - TÖRÖCSIK, M. (2018): Kultúra. A magyar lakosság kultúrával kapcsolatos beállitódása és követett magatartása generációs szemléletü vizsgálattal. Kézirat. EFOP-3.6.1-16-2016-00004, PTE KTK, Pécs

PÁLFI, N. (2019): A kulturális és a társadalmi tőke mint versenyképességi tényező a szakirodalom tükrében. In Csath M. (szerk.): A versenyképesség-mérés változásai és új irányai. Dialóg Campus Kiadó, Budapest, pp. 137- 164.

PINKE-SZIVA, I. (2019): Városi turizmus: élménysürítés a „civilizáció legszofisztikáltabb kulturális termékei” között. In: IRIMIÁS, A. - JÁSZBERÉNYI, M. - MICHALKÓ, G (eds.) A turisztikai termékek innovatív fejlesztése. Akadémiai Kiadó, Budapest, pp. 19-30.

PISKÓTI, I. (2016): Régió- és településmarketing. Akadémiai Kiadó, Budapest

PUSZTAI, G. (2011): A láthatatlan kéztől a baráti kezekig: Hallgatói értelmezö közösségek a felsőoktatásban. Budapest: Új Mandátum, Budapest 
RÁTZ, T. - PUCZKÓ, L. (2002): Goethe, Humbert és Odüsszeusz nyomában avagy kulturális utak a turizmusban. Turizmus Bulletin, VI. évfolyam 3. szám, pp. 3-11.

RÁTZ, T. (2014): Az EKF-turizmus mint lehetséges niche termék: A kulturális turizmus egy különleges területének vizsgálata. Turizmus bulletin, XVI. évfolyam 2. szám, pp. 24-33.

RUDAN, E. (2010): The development of cultural tourism in small historical towns. Tourism \& Hospitality Management 10, pp. 577-586.

SAJTOS, L. - MITEV, A. (2007): SPSS kutatási és adatelemzési kézikönyv. Alinea Kiadó, Budapestt

SCANNELL, L. - GIFFORD, R. (2010): Defining place attachment: A tripartite organizing framework. Journal of Environental Psychology 30. pp. 1-10.

SOKOLOWICZ, M. E. (2019): Student cities or cities of graduates? The case of Lodz and its students declared preferences. Population, Space and Place 25(2), e2177. DOI: 10.1002/psp.2177

STRACK, F. (2018): Consuming or overconsuming? Sustainability in Hungarian medical hotels. International Journal of Spa and Wellness 1(1), pp. 1-19. doi:10.1080/24721735.2018.1445428

STRACK, F. (2019): Certified Spas - Spa towns and the others. In HOJCSKA, Á. E. (szerk.) Changing Spa Towns :2nd Science Papers of the Spa Towns. Magyar Fürdővárosok Szövetsége Egyesület, Tata, pp. 47-70.

SZABÓ, S. (2020): A fenntartható turizmus és a helykötődés kapcsolatának vizsgálata a Busójárás kontextusában. Turisztikai és Vidékfejlesztési Tanulmányok, V. évf. II. szám, pp. 78-91. DOI: 10.15170/TVT.2020.05.02.06

SZABÓ, Z. - HOJCSKA, Á. E. (2020): Rekreációs turisztikai fürdőszolgáltatások és azok igénybevételének összefüggés-vizsgálata egy SPA-szolgáltatónál. Recreation: A Közép-KeletEurópai Rekreációs Társaság Tudományos Magazinja 10. évf. 1. sz., pp. 36-39. DOI: 10.21486/recreation.2020.10.1.4

SZÉKELY, L. - SZABÓ, A. (2017): Magyar ifjúság kutatás 2016: az ifjúságkutatás első eredményei. Új Nemzedék Központ, Elérhető: http://www.ujnemzedek.hu/sites/default/files/magyar_ifjusag_2016_a4_web.pdf (letöltve: 2019.01.22.)

TÓTHNÉ KARDOS, K. (2016): A győri turizmus elemzése a lakosság véleményének figyelembevételével. Polgári Szemle, 12. évfolyam, 4-6. szám.

UNWTO - IPSOS (2019): Global survey on the perception of residents towards city tourism: impact and measures. Elérhetö: https://webunwto.s3.eu-west-1.amazonaws.com/s3fs-public/201909/finalfullreporteng.pdf (letöltve: 2020.02.04.)

UNWTO (2018): Definitions Committee on Tourism and Competitiveness (CTC). Elérhető: http://cf.cdn.unwto.org/sites/all/files/docpdf/ctcdefinitionsenweb.pdf (letöltve: 2018.07.21.)

URBÁNNÉ TREUTZ, Á. (2017): A helykötődés és a helyidentitás elméleti, településmarketing szempontú megközelítése. In: TORGYIK, J. (eds.): Válogatott tanulmányok a társadalomtudományok köréböl. International Research Institute sro, Komárno, pp. 137-148.

VONG, F. (2013): Relationships among perception of heritage management, satisfaction and destination cultural image. Journal of Tourism and Cultural Change 11:4, pp. 287-301. DOI: $10.1080 / 14766825.2013 .852564$ 
XIE, L., - RITCHIE, B. W. (2019): The motivation, constraint, behavior relationship: A holistic approach for understanding international student leisure travelers. Journal of Vacation Marketing 25(1), pp. 111-129. DOI: 10.1177/1356766717750421 